\title{
LACUNAS, TRUQUES E TITUBEIOS EM O ALIENISTA
}

\author{
Eloésio Paulo ${ }^{1}$ \\ UNIFAL-MG \\ (eloesio@gmail.com)
}

\begin{abstract}
Era uma vez um médico que resolveu curar a loucura. Para isso, abriu um hospital que ficou logo cheio de pacientes. Desse grande número de loucos, o médico concluiu que a loucura era mais abrangente do que sempre se havia pensado, e então ampliou bastante o conceito de insanidade. Isso resultou na multiplicação das internações, que por sua vez gerou uma revolta entre a população do lugar, uma pequena vila. Essa revolta foi reprimida pela polícia, e a partir daí o médico redobrou o ritmo das internações até que percebeu que $80 \%$ dos habitantes da vila estava no hospício. Essa proporção exagerada levou-o a deduzir que a verdadeira loucura era a normalidade, e então libertou todos os internos. Logo em seguida, começou a recolher ao manicômio as pessoas de comportamento exemplar, mas não encontrou muitas. O tratamento dessa nova "loucura" consistia em corromper moralmente cada paciente, o que não foi difícil, e logo o hospício estava novamente vazio. Essa facilidade de "cura" levou o médico a pensar que todos já eram previamente corruptos, e a partir disso ele passou a considerar-se o único cidadão íntegro e razoável do lugar. Então, declarou-se louco e internou a si próprio, morrendo um ano e meio depois sem ter conseguido "curar-se".
\end{abstract}

Uma redução de $O$ alienista ao essencial resultaria aproximadamente no resumo acima. $O$ enredo se apresenta simples e claro, possível razão de o relato ter ganhado inúmeras edições em livro separado, tornando-se independente de Papeis avulsos, volume no qual o autor o incluíra em 1882, poucos meses depois de terminada sua publicação em capítulos seriados na revista $A$ Estação, destinada majoritariamente ao público feminino.

\footnotetext{
${ }^{1}$ Professor associado III da Universidade Federal de Alfenas. Autor dos livros Teatro às escuras - uma introdução ao romance de Uilcon Pereira (1998), Os 10 pecados de Paulo Coelho (2008) e Literatura e ideologia em dois romances dos anos 1970 (2014).
} 


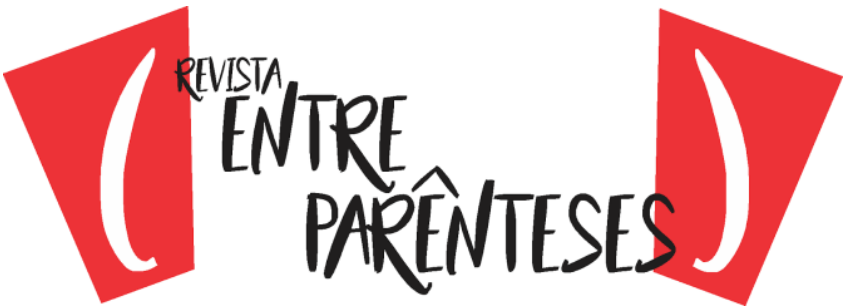

Mas a clareza e a simplicidade são um pouco enganosas. $O$ relato ambientado na minúscula Itaguaí do final do século XVIII tem características que o tornam, ao mesmo tempo, complexo demais para ser um conto e esquemático em excesso para ser um romance. Contudo, chamá-lo de novela, como têm feito muitos críticos, não resolve qualquer dos problemas que sua estrutura apresenta. Talvez seja mais sensato pensá-lo como uma charada de espécie parecida à que John Gledson (1986) enxergou em Casa velha, publicado em 1885, mas soaria sumário por demais pedir sua reclassificação "sem maiores cerimônias" como romance, a exemplo do que o estudioso britânico propôs em relação àquela narrativa, um inegável esboço de Dom Casmurro.

Teve razão Luiz Costa Lima ao usar O alienista, no seu famoso ensaio "O palimpsesto de Itaguai" (1991), como exemplo da tendência ao "sobrevoo" na crítica da obra machadiana, mas sua própria leitura deixou inexplorados aspectos importantes da estrutura do relato. E não só a de Costa Lima - em geral, os leitores profissionais se deixam iludir pela falsa simplicidade que já mencionamos. A decisão de chamar o relato de "novela" sem para isso exibir qualquer justificativa (pois o autor o incluiu em um livro de contos) já é sintomática. No caso de Costa Lima, o deslize interpretativo vai ao ponto de atribuir a Machado de Assis um grau de licenciosidade ausente no restante de sua obra: não há evidências textuais de que a mulher de Simão Bacamarte estaria, como diz o crítico, a queixar-se de um "comer figurado" com referência aos descuidos do marido quanto a seus deveres conjugais ou, mais especificamente, sexuais.

Extrapolaria nosso objetivo fazer aqui um levantamento exaustivo de deslizes do mesmo tipo, mas eles são bastante comuns na leitura de $O$ alienista. Há quem entenda errado qual foi o motivo de Dona Evarista para recusar o regime alimentício proposto pelo médico para curar-Ihe a suposta esterilidade; há quem veja nas atitudes do padre Lopes seu apoio à atividade do alienista e quem, ao contrário, qualifique o vigário de Itaguaí como vilão que encarna uma espécie de anticlericalismo não encontradiço na obra machadiana como um todo. De um modo geral, a simplicidade aparente do relato parece ter induzido até mesmo estudiosos do porte 


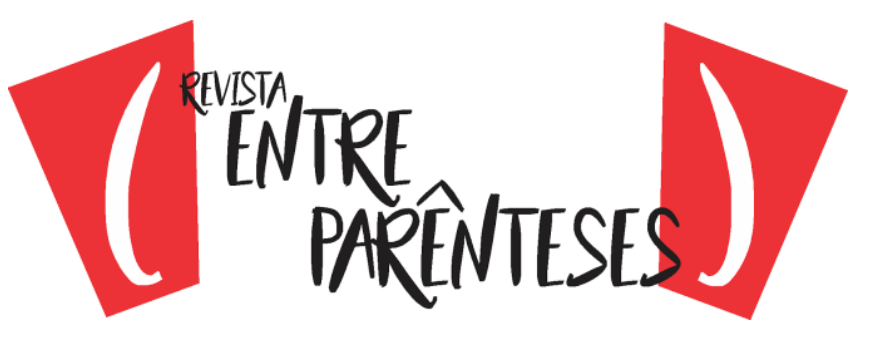

de Antonio Candido a considerá-lo um problema resolvido: visto como exemplar das principais características da ficção machadiana madura, $O$ alienista não mereceu nunca uma ampliação do irrepreensível parágrafo a seu respeito incluído no clássico "Esquema de Machado de Assis" (1977).

Um aspecto particularmente desconsiderado são as lacunas e ambiguidades do relato, algumas delas apresentando indícios de não serem intencionais. A principal é o fato de que a Casa Verde, onde deveriam se passar ao menos umas poucas cenas da história, é caracterizada de modo muito sumário: é um não-lugar, apesar de ser o espaço em que se daria o drama particular de cada indivíduo considerado louco pelo protagonista. Adiante veremos que essa caracterização, em sua sumariedade, acaba por configurar o hospício como instância inverossímil - e não é permitido pelas coordenadas do texto, a nosso ver, pensá-lo como espaço semelhante àquele em que se desenrola a trama de $O$ castelo (1922), de Kafka, pois o absurdo em $O$ alienista está no drama coletivo, que se passa quase inteiramente nas ruas e casas de Itaguaí. A fantasmagoria dessa presença in absentia pode ser perturbadora, mas principalmente não se encaixa nas demais peças narrativas. Falta algo.

Outro aspecto, bem diferente, são as razões para o deslocamento temporal e espacial que consiste em localizar o relato na Itaguaí do século XVIII. Quanto a isso, pensamos que a lacuna é mais da crítica do que do escritor, pois há motivos palpáveis para que Machado de Assis tenha resolvido não espelhar diretamente em sua ficção os dados do real que devem ter sido um ponto de partida para sua criação, a começar pelo Hospício de Pedro II. Imaginamos que a investigação profunda desses motivos passe pela consideração do projeto ficcional do escritor, pelas diretrizes que foi passando a impor-se com vistas a elaborar uma poética narrativa realista especificamente machadiana, e então de saída se apresentariam dificuldades relacionadas à prática impossibilidade de encaixar esse enredo no esquema de representação que, para começar, até hoje só foi razoavelmente esclarecido quanto aos romances, mas não quanto às narrativas curtas, e falamos de texto incluído em 


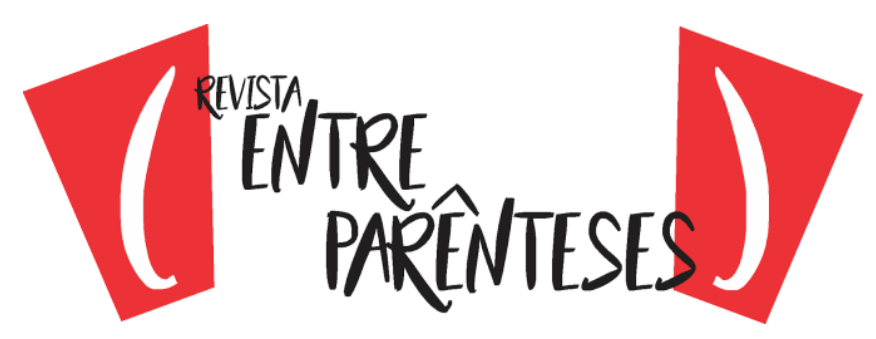

uma coletânea de contos. Em outra ocasião, pretendemos demonstrar como e por que o deslocamento espacial antecede o temporal e torna-o praticamente obrigatório.

Enumeramos a seguir algumas evidências de que os elementos amalgamados na construção do relato são mais variados e complexos do que normalmente se supõe, a começar pela recorrência das menções do narrador aos "olhos de metal" de Simão Bacamarte. Essas menções assumem, ao longo da narrativa, uma importância que chega ao excesso de dramaticidade e por isso acabam funcionando como ironia; as diferentes maneiras do médico de fixar objetos e, especialmente, pessoas, evoluem da impassibilidade exibida por ocasião da crise conjugal até a cegueira "para a realidade exterior" e a vidência "apenas para os profundos trabalhos mentais" que nos aponta o narrador no início da revolta dos Canjicas. A meio caminho, haviam-se coagulado naquele "olhar inquieto e policial" que "metia medo aos mais heroicos". Essa evolução do olhar de Bacamarte explicita o desenvolvimento de seu quadro maníaco, de que resulta um isolamento cada vez maior na sua certeza oposta ao mais elementar bom senso.

Significativamente, quando se instala o absurdo em nome da razão os olhos do alienista não precisam nos dizer mais nada. Apenas no desfecho, "acesos de convicção científica", denunciam o médico num estado análogo ao do transe místico e que prefigura a última verdade: sua própria perfeição solitária, ou seja, a loucura de sinal definitivamente trocado.

Dimensão pouco explorada do comportamento de Bacamarte é a retórica da autopromoção, que começa pelo emprego da expressão "louros imarcescíveis" para qualificar os futuros resultados de sua empreitada psiquiátrica. Ela colide com a modéstia exterior do alienista, e o próprio narrador é quem nos aponta a contradição; colide mais ainda com a ridicularização da pompa retórica ao longo do relato, da qual participa o próprio protagonista, especialmente em relação ao moço discursador Martim Brito, que "dava para o épico".

Mas, quanto à evolução do quadro maníaco, é talvez mais relevante observar a sistemática dissimulação do médico, adotada progressivamente à medida que encontra oposição a suas teses. Assim, se inicialmente não demora a confiar ao 


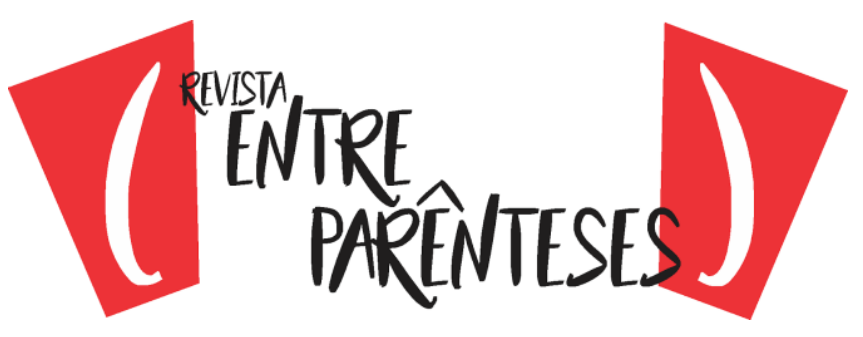

boticário Crispim "o mistério de seu coração", o sonho de se tornar notório por meio da psiquiatria, logo adiante evitará revelar-Ihe os casos concretos de itaguaienses que passariam a ser considerados loucos, preferindo mencionar apenas os exemplos históricos. Antes dessa mudança, Bacamarte falseara a origem do trecho do Alcorão inscrito na fachada da Casa Verde, e, diante da crise conjugal, engabelara Evarista com uma fala "macia como o óleo do Cântico" a fim de ver-se inteiramente livre para seus estudos.

No confronto com o chefe revoltoso é que a "rara sagacidade que o distinguia" se excede. A princípio surpreso com a mudança de ânimo do barbeiro Porfírio, que no dia anterior conclamara 300 cidadãos a destruir a Casa Verde, o alienista logo se recompõe, mas demora nada menos que três minutos para perguntar sobre os mortos e feridos. O que estivera pensando nesse silêncio tão longo para dois inimigos? Possivelmente, nos "lindos casos" de que a seguir se encarregaria, mas também, pode-se imaginar, em um truque para ludibriar o Canjica. Tamanho tato político toma outra forma, a da transigência, por ocasião da inversão de sua teoria da loucura: quando se aplica em recolher ao hospício as pessoas que julga perfeitamente equilibradas, aceita as restrições impostas pelos vereadores, pois o objetivo é proteger o único bem que the interessa: o poder de continuar internando quem the parecer "louco". Em última análise, Bacamarte protege sua própria vaidade.

\section{Revolução fajuta}

"Preso por ter cão, preso por não ter cão." A frase de Porfírio traduz a dialética ensandecida do método bacamartiano. Nesse rifão digno de Sancho Pança, possuir ou não um cachorro significam, respectivamente, ter liderado uma revolta e recusar-se depois a liderar outra. Mas a sentença também resume o principal movimento de um enredo que tem várias mudanças de andamento, pois a inversão do conceito de loucura é a grande reviravolta de $O$ alienista e explicita definitivamente a insanidade do personagem principal. A revolta dos Canjicas, momento mais tenso do relato, não passa de um interlúdio entre as duas teorias bacamartianas e de um 


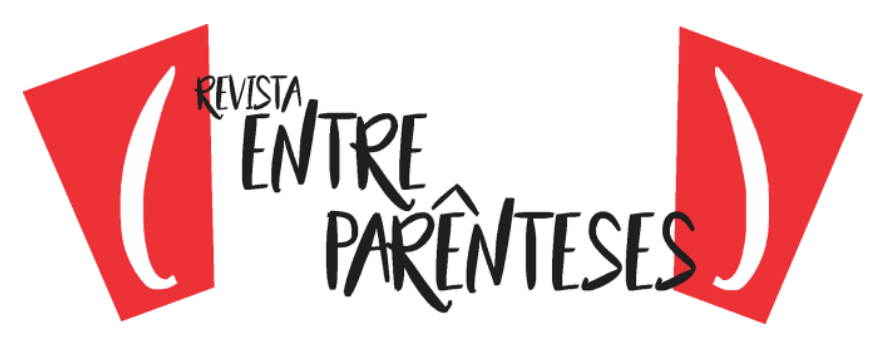

estopim para a transformação do "despotismo cientítifico" (palavras do barbeiro) em sistema totalitário - releve-se o anacronismo em função da intrigante premonição dos regimes que surgiriam no começo do século XX, se não for apenas uma evocação maliciosamente invertida do terror jacobino.

Vista em sua dimensão mais plana, a insurreição de Itaguaí é uma paródia da Revolução Francesa, remetendo algumas de suas passagens a fatos históricos de modo a encurtar, para dizê-lo como o narrador, a distância entre Paris e Itaguaí. Para começar, a tirania do alienista motiva tanto a revolta como o haviam feito as agressões do absolutismo às liberdades individuais na França pré-revolucionária.

Do interesse do escritor pela Revolução, dá conta o expressivo número de livros sobre o tema que restaram em sua biblioteca, assim como seu elogio de Louis Adolphe Thiers, estadista francês cuja morte o cronista lamentava em 1877 como "fato universal e de incalculáveis consequências". Thiers também foi o autor de dois volumes sobre a história da Revolução, ambos inventariados entre os livros que Machado de Assis teve permanentemente a seu alcance. Tamanho interesse talvez ajude a explicar outras coincidências entre a revolta dos Canjicas e o movimento francês, como o fato de uma parte da tropa oficial ter-se recusado disparar contra os populares, muitos soldados depois tendo-se juntado à insurreição.

Seria, porém, demasiado simplismo confinar o movimento liderado pelo barbeiro a essa paródia, assim como o é reduzir $O$ alienista a versão do Quixote. Pelas crônicas do escritor, sabemos que seu imaginário, no período imediatamente anterior à publicação do relato, esteve saturado de notícias e boatos sobre revoltas e tentativas de golpe no Brasil e em países vizinhos, especialmente Argentina e Paraguai. Em chave local, esses movimentos ganham ares de farsa, pois o barbeiro Porfírio vira a casaca do mesmo modo que muitos liberais e conservadores na política do Império. Para Machado de Assis, segundo alguns de seus mais autorizados intérpretes, a história do Brasil era toda uma paródia, e houve quem tenha percebido correspondências entre a revolta dos Canjicas e, por exemplo, os movimentos que ficaram conhecidos como Sabinada e Balaiada, sendo a primeira semelhança evidente o fato de cada um deles ter levado o nome de seu líder. 


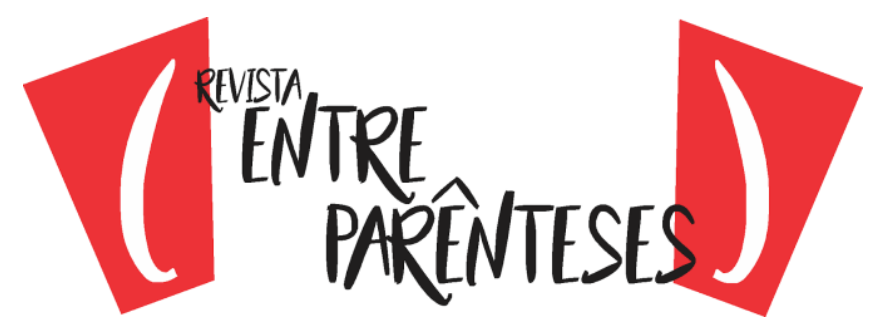

Seria o Motim do Vintém, tudo indica, a revolta local mais influente no imaginário subjacente ao relato. Esse movimento é pouco anterior ao início da publicação de $O$ alienista, pois ocorreu no início de 1880 , quando é possível que a aventura de Simão Bacamarte já existisse ao menos em esboço. Sobretudo uma dimensão contribuiu, por ser novidade chocante, para que aquele levante popular produzisse efeitos profundos e duradouros na vida política do Império: a violência em larga escala nas ruas do Rio de Janeiro, de que resultaram três mortos e ao menos 15 feridos.

Não cabe neste ensaio análise mais detida das correspondências desse tipo, que são relativamente numerosas e estão a merecer maior atenção dos estudiosos com foco nas representações machadianas da História. Sigamos, pois, em nossa pretensão de apontar elementos estruturais até hoje pouco notados do relato machadiano.

\section{O vigário de Itaguaí}

Quem mais aparece em $O$ alienista, de modo a justificar o título da narrativa, é Simão Bacamarte, mencionado 49 vezes. Em segundo lugar ficam as intervenções do narrador (30), que o transformam num personagem bastante influente, circunstância pouco notada pelos críticos. Em terceiro lugar vem o padre Lopes, que está em cena ou é referido 16 vezes, mais de uma por capítulo. Além de aparecer muito, o vigário de Itaguaí surge em cena em quase todas as passagens mais significativas do enredo, especialmente no início e no desfecho, quando se insinua pela primeira vez e quando se confirma que Simão Bacamarte era o maior de todos os loucos do povoado, senão o único. Mas, bem ao contrário da fanfarra verbal que ressoa ao fundo da revolta dos Canjicas, a participação de Lopes é discreta na mesma proporção da importância de suas aparições, sempre pontuais e quase meteóricas.

As relações entre ele e o alienista, a princípio, são bastante cordiais, mas o padre se mostrará quase ríspido e até, para seus padrões, prolixo quando 


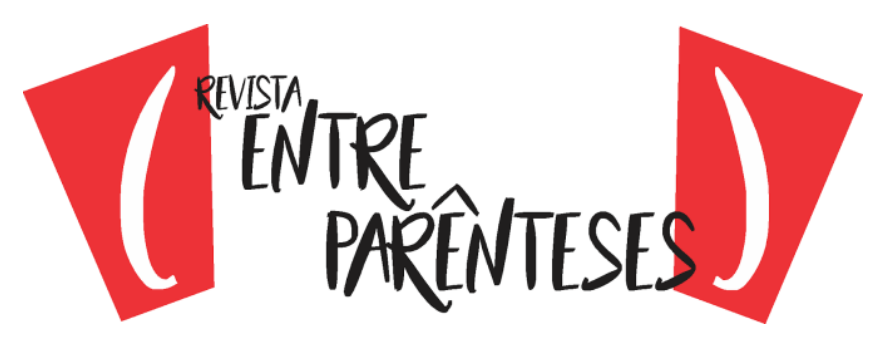

Bacamarte the anuncia a ampliação do conceito de loucura. Declarando "lisamente" que não chegava a entender a nova teoria, Lopes qualifica-a como "absurda" e diz que, ainda que não o fosse, era "de tal modo colossal que não merecia princípio de execução". A partir dessa oposição aberta, o vigário seguirá o médico a distância, porém rebaixado, à vista do outro, a alguém que não se deveria mais temer ou respeitar, mas se tornara de súbito digno de piedade e desdém.

Estabelecido assim o novo limite do diálogo entre ambos, o padre Lopes passará a ser mais cauteloso. Assim é que não intervém em favor de seu amigo Mateus, o albardeiro; deixará para fazê-lo indiretamente, questionando a mulher do médico com a insinuação de que talvez nem todos os internos da Casa Verde sejam loucos. Aos poucos se firma como um temeroso (afinal, já estava evidente a loucura do alienista) questionador do método bacamartiano.

Deixemos de lado a enigmática (à primeira vista) referência do narrador ao "ódio" que o padre sentia por Coelho, eminente caceteador dos itaguaienses que caíam nas malhas de sua conversa comprida e enfadonha. Mais importante é a passagem em que, intimado a celebrar um Te Deum pela vitória dos Canjicas, Lopes recusa aderir aos revolucionários com o mesmo desassombro que demonstrara diante do primeiro anúncio de absolutismo psiquiátrico. Essa demonstração de equidade deveria ser mais levada em conta, pois claramente milita contra a tese de que a caracterização do vigário seja sintoma de anticlericalismo da parte de Machado de Assis.

As próximas atitudes de Lopes serão igualmente cuidadosas. Quando da internação de Evarista, ele vai ao médico e não se satisfaz com a explicação da "mania sumptuária" com que este justifica o diagnóstico da mulher; no entanto, "não objetou nada". E por que o faria, se já agora a insanidade do médico saltava definitivamente à vista de todos, fazendo-se acompanhar de tamanha soma de poder que até os "principais da vila" estão arrependidos de não ter apoiado os Canjicas?

Será por esse comedimento, talvez, que o vigário se torna um dos poucos cidadãos itaguaienses dignos, segundo a teoria invertida da loucura, de reclusão na Casa Verde. Livra-se do hospício com um desembaraço que parece descaramento, 


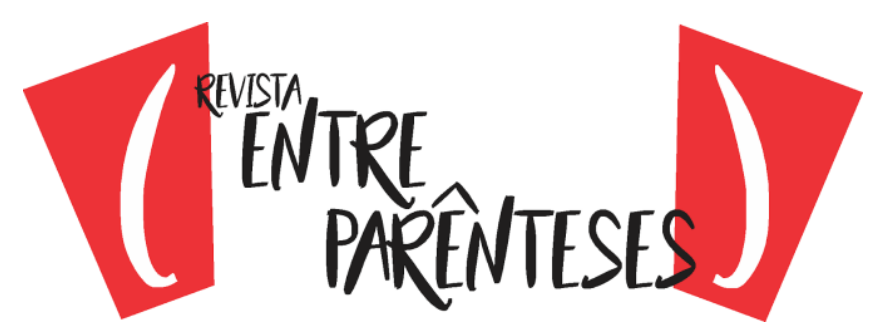

pois em dois meses conclui um trabalho intelectual que não seria, segundo o narrador, capaz de fazer. Mas tal desenvoltura tem explicação bastante plausível no desfecho, quando o mesmo Lopes é quem, diante das dúvidas do alienista quanto à própria condição de único indivíduo perfeitamente equilibrado de Itaguaí, convence-o de que a modéstia é uma qualidade superior que the "realça as outras".

Ao contrário de se mostrar um ser mefistofélico em que se corporificam todas as perfídias do clero (houve quem o interpretasse assim), o padre nos evoca, com essa atitude, a resposta de Beraldo a Angélica na peça $O$ doente imaginário, de Molière, quando a moça o questiona sobre estarem enganando Argan: "Sobrinha, não nos divertimos à sua custa, apenas nos pomos à altura de suas fantasias." Ou, buscando o conceito na própria obra machadiana, assim reflete o Monsenhor Caldas no conto "A segunda vida": condescender é "política útil com os loucos, as mulheres e os potentados".

Afinal, a verdade estivera desde o princípio com Lopes, primeiro a insinuar a falta de juízo de Bacamarte e último a declará-la, já morto o alienista, sem embargo da ressalva sonsa do narrador, de que o boato sobre a loucura do médico é "duvidoso" por ser atribuído à mesma pessoa que "com tanto fogo realçara as virtudes do grande homem". O comentário tropeça na mais elementar falta de lógica, assim como a afirmação de que seria um "epigrama ininteligível" dizer que o albardeiro Mateus ficaria mais rico se fabricasse arreios para si mesmo.

\section{O narrador sonso}

Ao postular que um escritor de ficção "não pode escolher" evitar a retórica, mas apenas optar pelo tipo de retórica que usará, Wayne Booth (1983) observa que eleger o foco narrativo de primeira pessoa é só um passo inicial, pois há vários tipos de primeira pessoa e mesmo alguns narradores "confiáveis" deixam escapar comentários que os tornam pouco dignos de crédito, no sentido de que podem ser considerados "potencialmente enganosos". A posição do narrador em $O$ alienista ilustra muito bem essa tese de Booth e tem sido negligenciada pelas leituras mais 


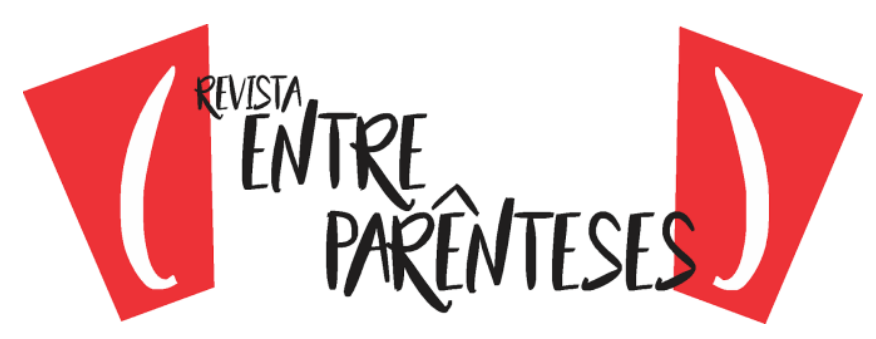

acuradas, o que é intrigante, dados a localização dessa obra no caminho evolutivo da ficção machadiana e o consenso quase unânime, desde os anos 1960, de que uma das características mais salientes da obra madura de Machado de Assis é a enunciação que refrata os fatos narrados.

O narrador sem nome, no caso, esconde-se atrás de uns muito indefinidos "cronistas antigos", e já por isso deveria convocar à prontidão o leitor atento, pois seus comentários, decididamente, não são ornamentais; ao contrário, servem a um propósito retórico e fazem parte da estrutura dramática do relato. É um narrador intrometido, abertamente irônico e por vezes contraditório: o típico narrador que, nas palavras de John Gledson (1991), está na base do "realismo enganoso" congenial à ficção machadiana pelo menos desde Memórias póstumas de Brás Cubas (1881).

De saída, por que haveria mais de um cronista encarregado de escrever sobre Itaguaí, povoado minúsculo a ponto de contar com apenas um exemplar de cada profissão, de acordo com a visão esquemática da "vila" que o narrador nos apresenta? Se há um segundo barbeiro, um "médico sem clínica" e um padre ocasionalmente de passagem pelo povoado, essas duplicações se dão por razões puramente incidentais, pois do contrário haveria razões para existir um segundo albardeiro, outro boticário e assim por diante. Itaguaí é um "universo" propositadamente pequeno para que fique sublinhado seu status de redução esquemática do Rio de Janeiro contemporâneo à escrita do relato. Assim, a existência de mais de um manuscrito historiográfico seria muito improvável, e além disso a voz narrativa que encobre a dos autores originais pertence a alguém cuja posição quanto aos fatos narrados é estruturalmente ambígua: alguém que precisa acreditar nos "velhos cronistas", mas, quando refere minúcias domésticas ou filigranas psicológicas obviamente fora do alcance de um cronista provinciano do século XVIII, precisa converter-se em testemunha onisciente.

O foco narrativo em $O$ alienista confere com a observação de Booth de que narradores propensos a comentar o que relatam são "peculiarmente tentados a ser pomposos e redundantes" (1983, p. 17). As redundâncias, se existirem, serão poucas, mas em termos de pompa retórica o narrador puxa a fila, sendo logo seguido pelo 


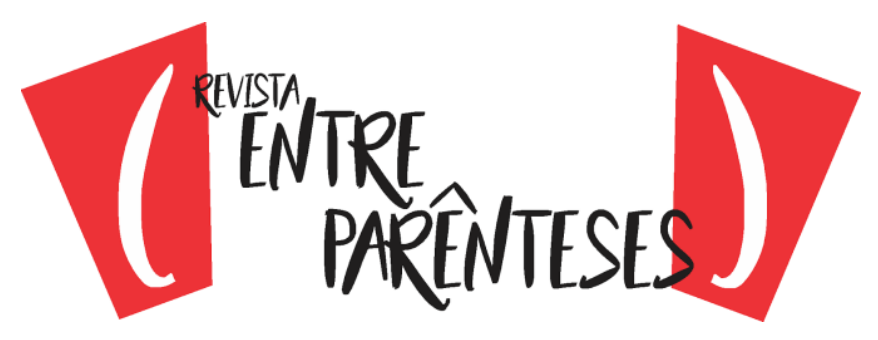

protagonista e por vários outros personagens. A diferença é que estes, quando lançam mão de "louros imarcescíveis" ou "turbilhão de átomos dispersos", estão falando sério, enquanto aquele emprega muitas vezes um tom de burla que acaba tornando-se, por acumulação, a nota dominante do relato.

Como é que o mesmo sujeito que faz, a princípio, o panegírico de Simão Bacamarte, dando-Ihe credenciais de luminar da ciência acreditado junto à Corte, poderá em breve chamá-lo de "terrível médico" e logo outra vez de "ilustre", mas atribuindo-Ihe uma "aleivosia"? Há uma oscilação opinativa que não pode ser debitada aos velhos cronistas. Mesmo quando afirma estar transcrevendo esses autores, 0 narrador deixa entrever atrás de si um alter ego zombeteiro, como a dizer que não seria grande coisa ser o "maior dos médicos do Brasil, de Portugal e das Espanhas" numa época em que a prática da medicina ia pouco além de sangrias e beberagens de efeito duvidoso.

Vários lances da narrativa não podem ser atribuídos aos cronistas de Itaguaí, como é o caso do comentário sobre a resistência de Evarista - "explicável, mas inqualificável" - ao regime alimentício proposto pelo marido. No capítulo III, as observações do narrador se tornam no mínimo impertinentes: quando atribui à mulher do alienista um poder encantatório capaz de "degolar a ciência", contradiz a descrição de Evarista como "mal composta de feições", mas principalmente atribui a Simão Bacamarte uma suscetibilidade que destoa do metal "duro, liso, eterno" de seus olhos. Transitando entre a retórica pomposa e o falseamento de sua própria posição, pois detalhar diálogos íntimos não seria tarefa de um velho cronista, o narrador se deixa surpreender como o que realmente é: um veículo para a ironia do autor.

No decurso da narrativa, atribuirá aos cronistas opiniões improváveis, como a insistência no fato de que Crispim Soares amava Cesária, sua "senhora máscula". Mete-se, além disso, pela psicologia de diversas personagens, especialmente o protagonista, a esposa deste e o barbeiro Porfírio. E sua bufonaria se explicita de vez no já citado comentário a respeito do albardeiro Mateus: se arreios são para as alimárias e Mateus os fabricava, segue-se a conclusão elementar de que os itaguaienses que pilheriavam a respeito do assunto estavam insinuando ser esse 


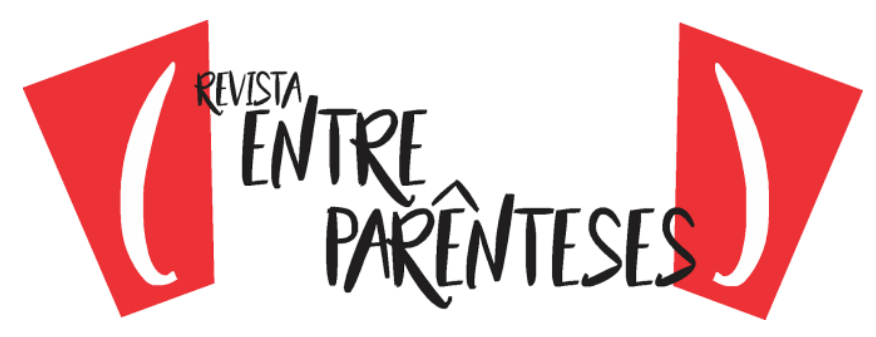

cidadão um asno ou cavalo. Não há nenhum "epigrama ininteligível”, o narrador finge que não entendeu a chalaça.

Suas interferências, portanto, parecem evidentes "passos consecutivos em nossa familiarização" (1983, 208) com ele, cuja função é a mais comum, segundo Booth, para um "comentador" que se imiscui nos fatos que relata: dizer aos leitores coisas que eles não poderiam saber de outro modo. Em $O$ alienista a posição do narrador é tão determinante para o efeito da narrativa que, sem maiores discussões, podem ser dadas como falhas todas as abordagens interpretativas que a desconsideram. E elas são a maioria.

O relato vai bem adiantado quando pela primeira vez a opinião dos cronistas é colocada em dúvida, pois "alguns" deles - e então podemos saber, por dedução lógica, que eram no mínimo três - pensavam que Simão Bacamarte nem sempre havia agido com lisura. Aí o narrador se perde em considerações sobre os motivos do alienista para armar um estratagema com o objetivo de diagnosticar mais loucos em Itaguaí, concluindo que as motivações do médico são "um dos pontos mais obscuros da história" da vila, quando é óbvio para o leitor mais distraído que o único objetivo era fazer os maníacos se denunciarem como tais. A progressiva importância dessas intromissões do narrador chega a seu ponto alto no desfecho, quando ele reputa "duvidoso" o boato atribuído ao padre Lopes, sendo suficientemente claro que os elogios do vigário ao alienista tinham a deliberada função de precipitar Bacamarte em seu inevitável suicídio lógico.

\section{Truques e titubeios}

Além do mencionado número de referências ao protagonista e ao padre (que, pelo contraponto, torna-se ao menos um antagonista "estatístico"), às quais se sobrepõe a constante intrusão do narrador, existem outros aspectos estruturais do relato que normalmente passam despercebidos. Um deles é o fato de que - ainda pensando nos termos da concepção de retórica narrativa exposta por Wayne Booth a história de Simão Bacamarte está delimitada, em seu princípio e no desfecho, pela 


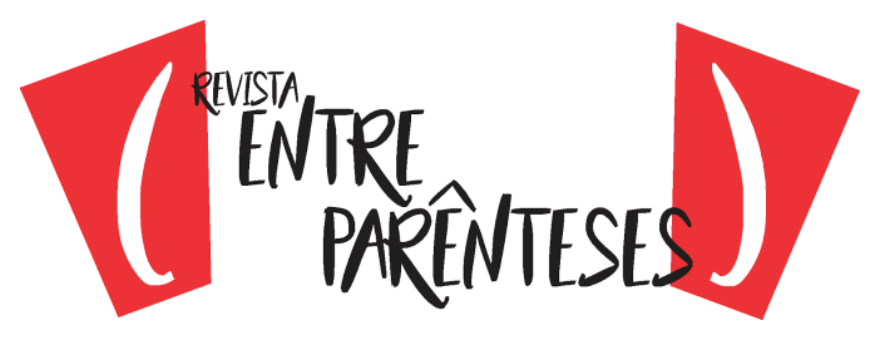

pompa e pelo nada. Quanto à primeira, veja-se o espelhamento entre a menção do narrador aos festejos por ocasião da abertura da Casa Verde e sua referência lacônica à "muita pompa e rara solenidade" do enterro do alienista.

Quanto ao nada, aparece na previsão de um vereador, logo no primeiro capítulo, de que os cálculos do escrivão eram inúteis, pois "o Dr. Bacamarte não arranja nada"; apesar de contradita pelo resultado imediato do empreendimento psiquiátrico, a previsão é confirmada pelo desfecho, que a corrobora em ponto maior, pois tanto a Casa Verde como a vida do alienista, no fim das contas, dão em nada.

Entremeando esses marcos, há outros que sinalizam as diretrizes retóriconarrativas do escritor. O primeiro é a advertência do padre Lopes de que o excesso de estudos podia "virar o juízo" do médico, adiante repercutida pelo trocadilho (repleto de intenções irônicas) posto na conta do vereador Sebastião Freitas: "se tantos homens em quem supomos juízo são reclusos por dementes, quem nos afirma que o alienado não é o alienista?". A sequência de sinais, que não terá sido inscrita por acaso na malha narrativa, é encerrada pela menção do narrador ao "boato" de que Bacamarte houvera sido o único verdadeiro louco de Itaguaí.

Ao dispor (no sentido que tem a dispositio na retórica de Quintiliano) os elementos do enredo com tamanha precisão, Machado de Assis lança mão de recursos bem codificados no teatro de Molière, que tanto apreciava e conhecia, e faz toda a estrutura narrativa convergir num dos processos mais característicos da comicidade (segundo Bergson): a inversão por meio da qual "o personagem prepara a trama na qual ele mesmo acabará por enredar-se". Também serve como luva, no caso, o registro de que "um personagem cômico o é, em geral, na exata medida em que se ignore como tal". A estrutura teatral é uma das formas mais úteis para compreender $O$ alienista, equiparando-se ao enredo folhetinesco de alguns dos chamados "contos filosóficos" de Voltaire, na verdade mais apropriados a serem chamados de "novela" do que o relato machadiano.

A consideração de tais aspectos estruturais, a maioria dos quais ainda inexplorados pela crítica, levaria a um detalhamento que também não cabe aqui. Não deixemos de mencionar, porém, um deles: a marcação temporal que dita o ritmo da 


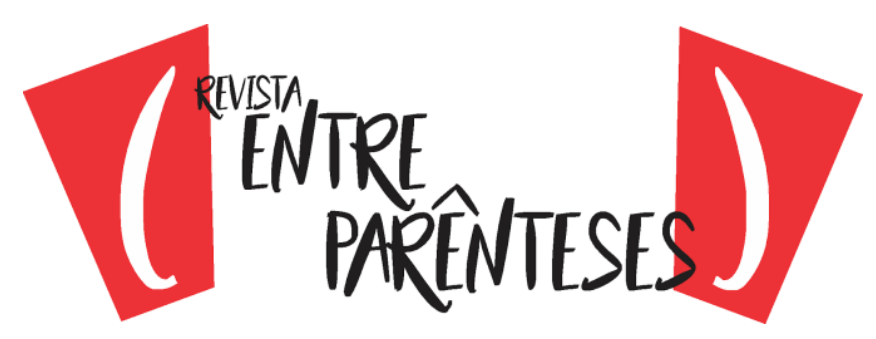

narrativa. Os dois parágrafos iniciais, por exemplo, consomem nada menos que seis anos, sendo o tempo narrativo, em seguida, distendido ou condensado segundo propósitos retóricos muito bem calculados, os quais devem ser responsáveis pelos admiráveis efeitos cuja fórmula os leitores costumam buscar na interpretação, a qual tende a falhar se não for antecedida de um detido exercício de close reading. A leitura preferencialmente contextual parece que tende a atrapalhar a compreensão de $O$ alienista.

É necessário encerrar este ensaio, para cumprir o prometido no título, mostrando alguns titubeios do autor. Eles são importantes porque conduzem a uma hipótese que, até onde sabemos, ainda não foi aventada: a de que $O$ alienista, apesar de todas as suas qualidades, é um texto inacabado. A nosso ver, investigações posteriores sobre esses aparentes defeitos na arte-final do relato são uma senda promissora para o esclarecimento de problemas que podem tornar-se importantes para uma compreensão mais apurada e transversal do que foi o desenvolvimento da poética narrativa de Machado de Assis. Não é por acaso, a nosso ver, que $O$ alienista se situa na confluência entre os dois modos narrativos machadianos, o da fase de aprendizado e o da fase resoluta e continuamente experimental, cujo marco zero é usualmente situado na publicação de Memórias póstumas de Brás Cubas, em apressada desconsideração de ousadias que vinham sendo ensaiadas ou praticadas em contos e crônicas pelo menos desde 1875 .

O primeiro titubeio é de natureza historiográfica. Apesar de o escritor ter-se empenhado, como de hábito, em lastrear a ambientação do relato em dados históricos, cometeu o engano de promover Itaguaí a vila ainda no século XVIII, sendo que no mundo real isso ocorreu somente em 1830. Também o número de vereadores de sua câmara, pela contagem que podemos fazer, era maior do que poderia ter uma vila, pois estudiosos da estrutura política colonial afirmam que eles seriam no máximo a quatro, mas em $O$ alienista contamos ao menos cinco.

Seriam meras distrações, ou falhas assim, na obra de um escritor geralmente tido na conta de perfeccionista, indicariam que ele não conseguiu, quaisquer que tenham sido os motivos, dar ao texto o acabamento que gostaria? $\mathrm{A}$ 


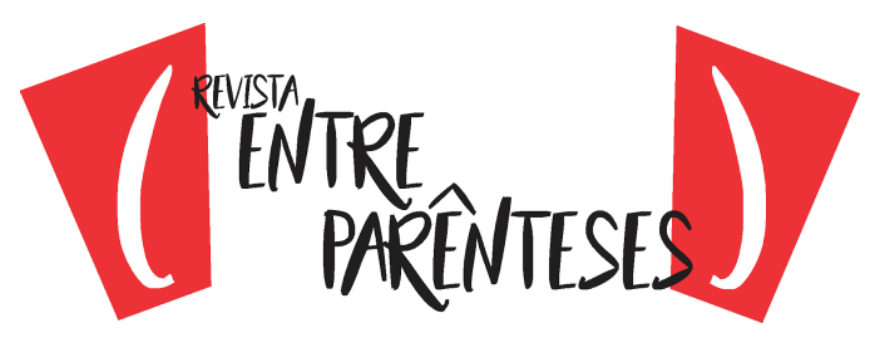

nosso ver, outros furos mais importantes tornam viável uma aposta na segunda hipótese. O mais estranho deles, sem dúvida, é de natureza matemática: a superlotação da Casa Verde é incompatível, numericamente, com a quantificação que o narrador apresenta relativamente às vagas disponíveis naquele estabelecimento.

Logo no segundo capítulo, informa-nos ele que, devido à "torrente de loucos" que acorriam a Itaguaí, fora necessário acrescentar 37 novos cubículos à Casa Verde. Não sabemos o número inicial de vagas, apenas quantas janelas tinha o hospício. Ocorre que em seguida são recolhidos 123 pacientes sem que nenhuma nova ampliação tenha sido mencionada. Pior: isso se dá antes de iniciada a "coleta desenfreada" de que resulta a internação de $80 \%$ dos cidadãos itaguaienses, com a agravante de que sabemos serem muitos dos pacientes oriundos de outras localidades. Não há outra explicação: houve um cochilo do autor quanto ao compromisso com a verossimilhança, tão escrupulosamente cuidado, ao contrário, na definição do foco narrativo e em outras opções técnicas de relevância menor.

Há outros. Por exemplo, é discutível que a dedicação do alienista "inteiramente ao estudo e à prática da medicina" mostre como a ciência "tem o inefável dom de curar todas as mágoas", embora essa afirmação do narrador se coadune com a intenção de ironizar o verdadeiro motivo do mergulho de Bacamarte nos estudos. É que antes do casamento, e sem motivo semelhante, já o médico se havia entregado "de corpo e alma ao estudo da ciência, alternando curas com leituras, e demonstrando os teoremas com cataplasmas". No mínimo, há aqui uma duplicação cujo papel na economia narrativa é difícil explicar.

Mais importante, porque claramente incoerente, é a reflexão de que Evarista não podia perder a chance de conhecer o Rio de Janeiro, "agora, principalmente, que o marido assentara de vez naquela povoação interior". Ora, ela se casara com um Simão Bacamarte já plenamente convicto de que Itaguaí era seu "universo", ao passo que o pensamento que lhe atribui o narrador seria apropriado a quem fosse mulher de um médico anteriormente itinerante.

Há ainda a informação de que o vereador Galvão, mesmo preso na Casa Verde, conseguiu corromper juízes e embaçar herdeiros concorrentes à herança de 


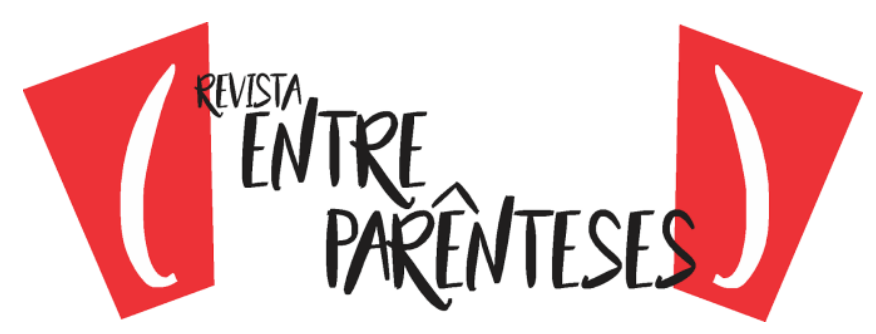

um tio. Ela suscita várias perguntas que exigiriam algum detalhamento, enquanto outras passagens do relato contêm o correspondente oferecimento de dados esclarecedores das circunstâncias. Outra pergunta que se impõe: haveria "juízes" em Itaguaí, ou povoado tão pequeno poderia, na melhor das hipóteses, contar com um único desses magistrados?

O tecido narrativo de $O$ alienista apresenta, pois, lacunas que não temos razões para supor que tenham sido intencionais. É o caso desta outra situação opaca: se o protagonista era "filho da nobreza da terra", por que em nenhum momento nos parece (antes, parece o contrário) fazer parte dos "principais da vila"? Onde estão seus parentes, o único dos quais a comparecer ao enredo é aquele tio "caçador de pacas perante o Eterno", e apenas a propósito de fazer seu comentário jocoso sobre a escolha, pelo sobrinho, de uma esposa "nem bonita nem simpática"?

A hipótese mais apta para conduzir à elucidação desse inacabamento, numa obra tão unanimemente aceita como um dos ápices da inventiva machadiana, parece-nos que pode sair da consideração das circunstâncias em que se deu a publicação de $O$ alienista em livro, poucos meses depois de sua conclusão como folhetim nas páginas de $A$ Estação. É um problema para cujo equacionamento admitimos ter dado, até aqui, apenas os primeiros passos. O mais importante deles, pretendemos que tenha sido evitar a costumeira leitura de sobrevoo.

\section{REFERÊNCIAS}

1. Obras de Machado de Assis

ASSIS, J.M.M. de. Obra completa. São Paulo: Nova Aguilar, 2015

\section{Outras obras literárias}

MOLIÈRE. EI medico a palos/ El enfermo imaginário. Santiago de Chile: Editora Zig-Zag, 2005.

. O Tartufo/ O Misantropo. São Paulo: Martins Fontes, 2005. 


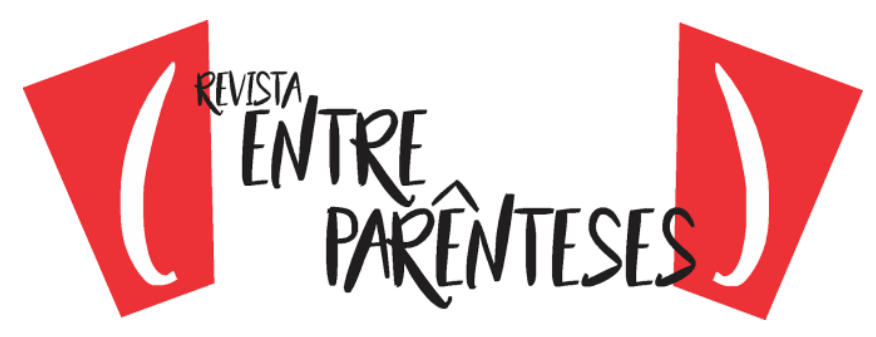

SWIFT, J. Serious and useful scheme to make na hospital for incurables. Londres: J. Roberts, 1733.

A tale of a tube. Mineola: Dover Publications, 2017.

VOLTAIRE. Contos. São Paulo: Abril Cultural, 1983.

\section{Sobre $O$ alienista}

BARBIERI, I. O alienista: a razão que enlouquece. Em: Revista Brasileira, Fase VII, ano IV, n. 14, jan.-mar./1998.

CHAUVIN, J. P. O Alienista - a teoria dos contrastes em Machado de Assis. São Paulo: Reis Editorial, 2005.

COSTA LIMA, L. O palimpsesto de Itaguaí. Em: Rio de Janeiro: 1991, Rocco, p. 251-265. Pensando nos trópicos.

FISCHER, L.A. Uma coisa e nenhuma delas: 'O alienista'. Em: Machado e Borges e outros ensaios sobre Machado de Assis. Porto Alegre: Arquipélago Editorial, 2008, p. 197-214.

GOMES, R. O Alienista: loucura, poder e ciência. Em: Tempo Social, no5 (12), 1994, p.145-160.

MOISÉS, M. O Alienista de Machado de Assis, uma paródia de D Quixote? Em: Jornal da Tarde - Caderno de Sábado, 8/1/2000, p. 1-3.

MURICY, K. A razão cética; Machado de Assis e as questões do seu tempo. São Paulo: Companhia das Letras, 1988.

PAULO, E. Desinterpretando O alienista. Em: NUNES, A.M. et al. Olhares cruzados - percursos interpretativos. Campinas: 2014, Pontes Editores, p. 29-56.

SCHNAIDERMAN, B. 'O alienista', um conto dostoievskiano?. Em: Teresa - Revista de Literatura Brasileira, n. 6/7. São Paulo: Editora 34/Imprensa Oficial, 2006, p. 268273.

SECCHIN, A. C. Linguagem e loucura em 'O alienista'. Em: Poesia e desordem. Rio de Janeiro: Topbooks, 1996, p. 186-192.

TEIXEIRA, I. O altar e o trono. São Paulo: Ateliê, 2010, p. 238. 


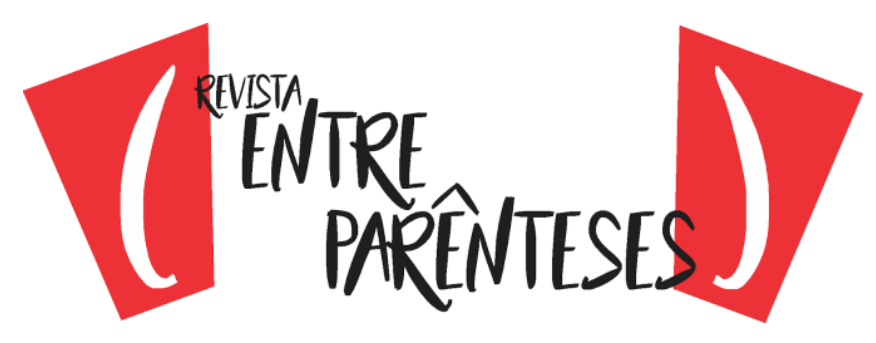

VIEIRA, M.A.C. O alienista de Machado de Assis: o Dom Quixote de Itaguaí. Em: Letras \& Letras, Uberlândia, ํㅜ 20(1), jan/jun 2004, p 77.

WOOD, M. Entre Paris e Itaguaí. Em: Novos Estudos no 83, mar/2009, p. 185-196.

\section{Sobre a obra de Machado de Assis}

BAPTISTA, A. B. Três emendas: Ensaios machadianos de propósito cosmopolita. Campinas: Editora da Unicamp, 2014.

BARRETTO FILHO. Introdução a Machado de Assis. Rio de Janeiro: Livraria Agir Editora, 1980.

BARROS, D.M. Machado de Assis: a loucura e as leis. São Paulo: Brasiliense, 2010.

BOSI, A. O enigma do olhar. São Paulo: Ática, 1999.

BRAYNER, S. As metamorfoses machadianas. Em: Labirinto do espaço romanesco. Rio de Janeiro: MEC/Civilização Brasileira, 1979, p. 51-118.

CANDIDO, A. Esquema de Machado de Assis. Em: . Vários Escritos. 2 ed. São Paulo: Livraria Duas Cidades, 1977, p. 13-32.

CASTELLO, J.A. Realidade e ilusão em Machado de Assis. São Paulo: Companhia Editora Nacional/Edusp, 1969.

CHALHOUB, S. Machado de Assis historiador. São Paulo: Companhia das Letras, 2003.

DANTAS, L.C.S. O Alienista de Machado da Assis: loucura e hipérbole. Em: RIBEIRO, R.J. et al. Recordar Foucault. São Paulo: Brasiliense, 1985, p. 144-152.

FANTINI, M. et al. Crônicas da antiga corte - Literatura e memória em Machado de Assis. Belo Horizonte: Editora UFMG, 2008.

GLEDSON, J. Machado de Assis: ficção e história. Rio de Janeiro: Paz e Terra, 1986. 1998. Machado de Assis: impostura e realismo. São Paulo: Companhia das Letras, Por um novo Machado de Assis. São Paulo: Companhia das Letras, 2006. 


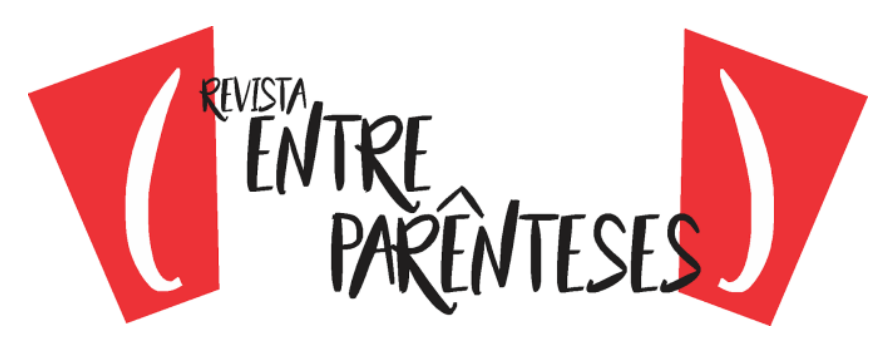

GOMES, E. Machado de Assis - influências inglesas. Rio de Janeiro: Pallas/INL, 1976.

GRIECO, A. Machado de Assis. Rio de Janeiro, Livraria José Olympio, 1959.

GUIDIN, M. L. et al. Machado de Assis; ensaios de crítica contemporânea. São Paulo: Editora UNESP, 2008.

GUIMARÃES, H.S. Machado de Assis, o escritor que nos lê. São Paulo: Editora da UNESP, 2017.

JOBIM, J.L. et al. A biblioteca de Machado de Assis. Rio de Janeiro: Topbooks/ABL, 2001.

LOPES, J.L. A psiquiatria de Machado de Assis. Rio de Janeiro: Agir/MEC, 1974.

MAGALHÃES JR., R. Machado de Assis desconhecido. São Paulo: LISA, 1971.

MANZANO, N. T. A volta de Simão Bacamarte. São Paulo: Textonovo, 2002.

MASSAINI, M.I. O tema da loucura na obra de Machado de Assis. Campinas: IFCH, 1992.

MAYA, A. Machado de Assis (algumas notas sobre o "humour"). Rio de Janeiro: ABL, 1942.

MERQUIOR, J. G. Machado de Assis e a prosa impressionista. Em: De Anchieta a Euclides. Rio de Janeiro: Livraria José Olympio, 1979, p. 150-205.

MEYER, A. Machado de Assis (1935-1958). Rio de Janeiro: José Olympio/ABL, 2008.

MOOG, V. Herois da decadência. Rio de Janeiro: Civilização Brasileira, 1964.

PEREGRINO JÚNIOR. Doença e constituição de Machado de Assis. Rio de Janeiro: MEC/José Olympio, 1976.

PEREIRA, Lúcia Miguel. Machado de Assis. Belo Horizonte: Itatiaia, 1988.

SCHWARZ, R. Que horas são? São Paulo: Companhia das Letras, 1987. 


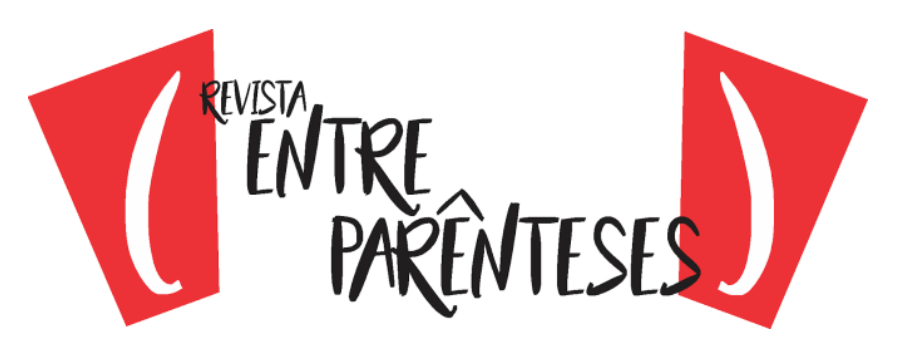

Ao vencedor as batatas. São Paulo: Livraria Duas Cidades, 1992.

. Um mestre na periferia do capitalismo /Machado de Assis/ São Paulo: Duas Cidades, 1990.

SOARES. M.N.L. Machado de Assis e a análise da expressão. Rio de Janeiro, Instituto Nacional do Livro, 1968.

SONTAG, S. Vidas póstumas: o caso de Machado de Assis. Em: Questão de ênfase. São Paulo: Companhia das Letras, 2005.

5. Geral

ARÊAS, V. Iniciação à comédia. Rio de Janeiro: Jorge Zahar Editor, 1990.

BARREIROS, E.C. As vilas del-rei e a cidadania de Tiradentes. Rio de Janeiro: José Olympio/MEC, 1976.

BERGSON, H. O riso; ensaio sobre a significação do cômico. Rio de Janeiro: Zahar Edições, 1983.

BERNARDI, J. A organização municipal e a política urbana. Curitiba: IBPEX, 2007.

BLUCHE, F. et al. A revolução francesa. Rio de Janeiro: Jorge Zahar Editor, 1989.

BOOTH, Wayne C. The rhetoric of fiction. Chicago: The Chicago University Press, 1983.

BRAGA, A. S. O poder político do município no Brasil Colônia. Em: Revista Brasileira de Direito Constitucional, n. 12, jul./dez. 2008, p. 169-232.

CALMON, P. O palácio da Praia Vermelha. Rio de Janeiro: Editora da UFRJ, 2004.

CASTEL, R. A ordem psiquiátrica: A era de ouro do alienismo. Rio de Janeiro: Edições Graal, 1978.

CHALHOUB, S. et al. A História contada; capítulos de história social da literatura no Brasil. Rio de Janeiro: Nova Fronteira, 1998.

COROACY, V. Memórias da cidade do Rio de Janeiro. Rio de Janeiro: José Olympio, 1965. 


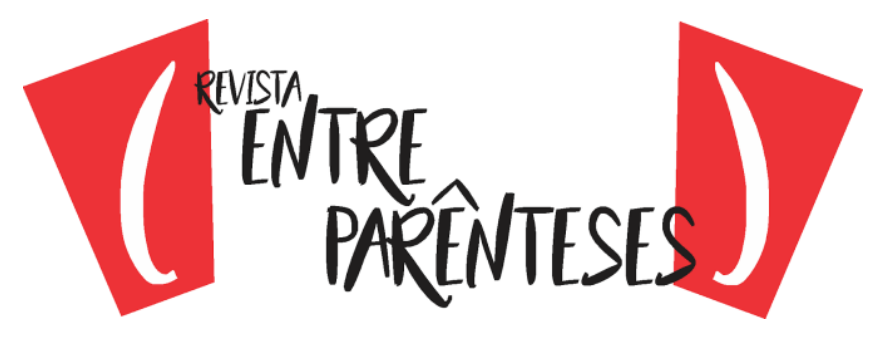

COSTA, J.F. História da psiquiatria no Brasil. Rio de Janeiro: Documentário, 1976.

D'ANGELI, C. e PADUANO, G. O cômico. Curitiba: Editora UFPR, 2007.

DANTAS, M.D. et al. Revoltas, motins, revoluções; homens livres pobres e libertos no Brasil do século XIX. São Paulo: Alameda, 2011.

EDMUNDO, L. O Rio de Janeiro do meu tempo, vol II. Rio de Janeiro: Imprensa Nacional, 1938. 1938.

O Rio de Janeiro do meu tempo, vol. III. Rio de Janeiro: Imprensa Nacional, O Rio de Janeiro no tempo dos vice-reis. Belo Horizonte: Itatiaia, 2000.

FELMAN, S. La folie et le chose littéraire. Paris: Éditions du Seuil, 1978.

FOUCAULT, M. História da loucura na idade clássica. São Paulo: Perspectiva, 1978.

FREUD, S. O chiste e suas relações com o inconsciente. São Paulo: Companhia das Letras, 2017.

GODECHOT, J. A revolução francesa: cronologia comentada (1787-1999). Rio de Janeiro: Nova Fronteira, 1989.

MEYER, M. Folhetim - uma história. São Paulo: Companhia das Letras, 1996.

MURAT, L. O homem que se achava Napoleão: por uma história política da loucura. São Paulo: Três Estrelas, 2012.

PELLEGRINI, T. Realismo; a persistência de um mundo hostil. Em: Revista Brasileira de Literatura Comparada, n. 14, 2009, p. 11-36.

PESSOTTI, I. Os nomes da loucura. São Paulo: Editora 34, 1999.

PORTER, R. Uma história social da loucura. Rio de Janeiro: Jorge Zahar Editor, 1995. 


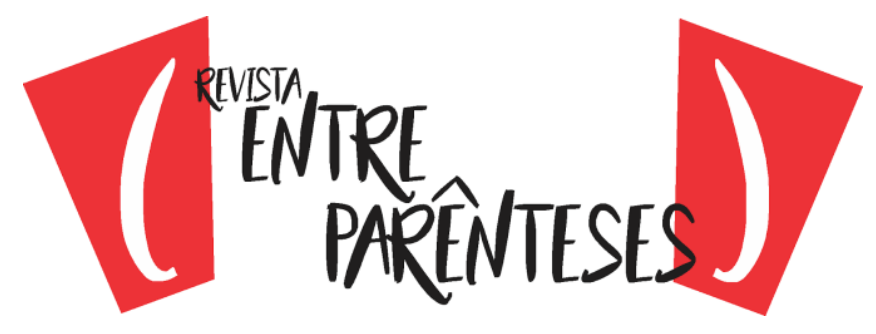

Das tripas coração. Uma breve história da medicina. Rio de Janeiro: Record, 2004.

RIGOLI, J. Lire le délire; alienisme, rhetórique et littérature en France au XIXe. Siècle. Paris: Fayard, 2001.

Resumo: Este ensaio pretende apresentar aspectos estruturais da narrativa $O$ alienista, de Machado de Assis, com vistas a delimitar a possibilidade de uma interpretação divergente das habituais. Partindo do pressuposto de que existem elementos textuais que tornam esse relato um constructo narrativo simples apenas em aparência, pretendemos discutir novas possibilidades para sua leitura que sejam baseadas em dados efetiva e indiscutivelmente inscritos na tessitura da obra.

Palavras-chave: Machado de Assis; $O$ alienista; Estrutura narrativa.

Abstract: This essay intends to show structural aspects of the tale $O$ alienista, by Machado de Assis, in order to delimit the possibility of an interpretation that differs from the usual ones. Starting from the assumption that there are textual elements turning this tale a simple constructed narrative only in the appearance, we bring to discussion new possibilities for its reading that are based on effectively and indisputable data enrolled in the tecitura of the work.

Keywords: Machado de Assis; O alienista; Narrative structure.

Resumen: Este ensayo pretende presentar los aspectos estructurales de la narrativa $O$ alienista, de Machado de Assis, con el objeto de delimitar la posibilidad de una interpretación divergente de las habituales. Partiendo de la presuposición de que existen elementos textuales que hacen de este relato un constructo narrativo simple solo en apariencia, pretendemos discutir nuevas posibilidades para su lectura, basadas en datos efectiva e indiscutiblemente inscritos en la tesitura de la obra.

Palabras-clave: Machado de Assis; $O$ alienista; Estrutura narrativa.

Recebido em 24/10/2018

Aceito em 30/11/2018

Revista (Entre Parênteses)

Número 7, Volume 1, 2018 - ISSN 2238-4502 